\title{
Introduction to the Special Issue: the Racial Wealth Gap
}

\author{
Sara Kamali ${ }^{1}$
}

Received: 10 July 2021 / Revised: 14 July 2021 / Accepted: 20 July 2021 / Published online: 19 August 2021

(c) The Author(s), under exclusive licence to Springer Nature Switzerland AG 2021

The COVID-19 pandemic has made clear the disparities between the America that most Black and Brown people experience and the America that many White people experience. These differences are evident in the multiple systemic inequities, including in wealth, specifically the racial wealth gap, which is the disparity in assets minus the amount of debt of typical households across skin color.

The racial wealth gap has deep roots within the institutions of the USA beginning with the prerequisite to own property, or pay taxes, to vote. The Founding Fathers relinquished election control to individual states. This decision resulted in both the restriction of voting to property owning, tax-paying, White men as well as the continued struggle of minoritized communities to exercise their vote. Thus, owning a home has been the central method to access the full spectrum of benefits and opportunities granted to the restricted category, "We the People", demarcated by the first words of the US Constitution. "We the People". Because of the legacy of housing covenants and redlining, neighborhoods and zip codes have continued to be divided along lines of color. Being denied the ability to own one's home means being denied the opportunity to build generational wealth and real estate wealth, because it is an asset that most certainly appreciates in value over time.

The result of making White skin color a prerequisite for home ownership skin color is the continuaction of the racial wealth gap that manifests as the segregation of social networks, stark differences in the quality of education, lack of access to green spaces and nutritious food, as well as disproportionately negative disparities in employment rates and in rates of incarceration Urban Institute, n.d (Epperson 2020).

The racial wealth gap also means that the median wealth of a White family is 10 times the media wealth of a Black family. Moreover, Black Americans can expect

Sara Kamali

kamali@ucsb.edu

1 Orfalea Center for Global \& International Studies, MS 2150, University of California, Santa Barbara, Santa Barbara, CA 93106-2150, USA to earn up to $\$ 1$ million less than White Americans over their lifetime. Black women, in particular, are most negatively impacted by lower earnings and limited access to capital (Goldman Sachs 2021; Noel et al. 2019).

Despite the myriad detrimental impacts of the racial wealth gap, the wealth gap between White and Black Americans specifically is underestimated as being $40 \%$ to $80 \%$ smaller than it is (Kraus et al. 2019). Such gaps in knowledge negatively reinforce the dehumanization of Black Americans, and point to the apathy to the inequities that many Black and Brown Americans face daily.

Moreover, until the racial wealth gap is acknowledged and recognized as a moral and economic problem, it will not be redressed systemically through policy. The purpose of the four contributions of this special issue of the Journal of Economics, Race, and Policy (JERP), all subject to external peer review, is to interrogate the underlying inequities that result in the racial wealth gap, which should more appropriately be termed the 'skin color wealth gap', and offer policy solutions to them. Additionally, the aim of this special issue is to meaningfully contribute to policy discussions and decisions to shift the racial wealth gap to financial equity for Americans of color on par with many of their White counterparts. Policy-oriented and solutions-based research peer-reviewed studies on the racial wealth gap have been few and far between. It is my hope, as editor of this special issue, that these articles will inspire more studies on the racial wealth gap that center Americans of color at the intersection of minoritized identities.

Petach and Tavani examine the role of discrimination in creating the racial wealth gap. They argue that both targeted investments in public education and in environmental goods in majority Black and Latinx neighborhoods will boost home values. Justice, not efficiency, should be the litmus test for economic action on racial inequity.

Bishop, Rodríguez, and Zeager investigate the differences in positional and directional earning mobility for Black and White Americans during their lifetimes, including important analysis along an intersectional lens, specifically through gender identity. 
Kroger and Wright analyze longitudinal data from the Panel Study of Income Dynamics (PSID) to illustrate both the opportunities and losses that business success or failure offers for Black and White entrepreneurs.

Weller, Maxwell, and Solomon utilize simulations anchored in data and the existing literature to conclude that baby bonds would have the single largest effect in ameliorating the racial wealth gap. They advance the argument that only targeted cash or liquid asset transfers to Black Americans can overcome the persistent wealth difference in comparison to White households.

I commend each author for participating in this special issue of the Journal of Economics, Race, and Policy. The policy recommendations detailed herein are timely, necessary, and consequential to advancing equity and achieving justice for Americans who have long been disproportionately denied access to wealth, and the access and benefits wealth provides, because of skin color.

My sincere thanks is extended to not only the authors, but also to the external reviewers for their time, diligence, and commitment during the COVID-19 pandemic. Undertaking research can be taxing at the best of times. To do so during a global public health crisis is exponentially so. Additionally, a special note of gratitude to Gary A. Hoover, the Editor of the Journal of Economics, Race, and Policy, for his professionalism, commitment to excellence, and consistency throughout the process of preparing this special issue for publication.

\section{References}

Epperson S. "Black corporate, nonprofit leaders say protests point to America's racial wealth gap, offer solutions," June 2, 2020, CNBC. https://www.cnbc.com/2020/06/02/protests-spur-blackexecs-to-weigh-in-on-americas-racial-wealth-gap.html. Accessed 11 Aug 2021.

Goldman Sachs. Black womenomics: investing in the underinvested, March 9, 2021, https://www.goldmansachs.com/insights/pages/ black-womenomics-f/black-womenomics-report.pdf. Accessed 11 Aug 2021.

Kraus MW, Onyeador IN, Daumeyer NM, Rucker JM, Richeson JA. The misperception of racial economic inequality. Perspect Psychol Sci. 2019;14(6):899-921. https://doi.org/10.1177/17456 91619863049.

Noel N, Pinder D, Stewart S, Wright J. "The economic impact of closing the racial wealth gap," McKinsey \& Company, August 13, 2019, https://www.mckinsey.com/industries/public-and-socialsector/our-insights/the-economic-impact-of-closing-the-racialwealth-gap\#. Accessed 11 Aug 2021.

Urban Institute. "Exposing housing discrimination," https://www. urban.org/features/exposing-housing-discrimination., n.d., https://www.urban.org/features/exposing-housing-discrimination. Accessed 11 Aug 2021.

Publisher's Note Springer Nature remains neutral with regard to jurisdictional claims in published maps and institutional affiliations. 